\title{
CPVC-könyökidomok optikai ellenőrzése és a gyártási folyamat hibadiagnosztikája
}

\section{Optical Inspection of CPVC Fitting Elbows and Fault Diagnosis of the Production Process}

\author{
Korsoveczki Gyula, ${ }^{1}$ Bencsik Balázs, ${ }^{2}$ Husi Géza ${ }^{3}$ \\ Debreceni Egyetem, Müszaki Kar, Mechatronikai Tanszék. Debrecen, Magyarország \\ ${ }^{1}$ korsoveczki.gyula@gmail.com \\ ${ }^{2}$ bencsikbalazs97@gmail.com \\ 3 husigeza@eng.unideb.hu
}

\begin{abstract}
The topic of this study is the optical inspection of CPVC fitting elbows concerning the geometric parameters that can be detected in 2 dimensions. Based on the evaluation of the results, fault diagnosis has been set up for the production line by statistical calculations. The optical inspection was carried out in the Vision Development Module software environment produced by National Instruments, and the data were evaluated using Microsoft Excel.
\end{abstract}

Keywords: Industry 4.0, image processing, quality control, CPVC, fault diagnosis.

\section{Összefoglalás}

A tanulmány során CPVC-anyagú könyökidomok optikai ellenőrzése valósult meg 2 dimenzióban detektálható geometriai paraméterekre vonatkozóan. Az eredmények kiértékelése alapján hibadiagnosztika került felállításra a gyártósorra vonatkozóan statisztikai számítások révén. Az optikai ellenőrzés a National Instruments Vision Development Module fejlesztőkörnyezetben valósult meg, az adatok kiértékelése pedig a Microsoft Excel használatával történt.

Kulcsszavak: Ipar 4.0, képfeldolgozás, minőség-ellenőrzés, CPVC, hibadiagnosztika .

\section{Bevezetés}

A jelenkori ipar, a gazdasági és társadalmi viszonyok egyik fő formálója a negyedik ipari forradalom, melyre gyakran csak Ipar 4.0-ként hivatkozik a műszaki élet.

Az Ipar 4.0 gépek és folyamatok intelligens hálózatában gondolkodik az információs és kommunikációs technológia segítségével. Mindinkább fontosabb szerephez jutnak a fejlett érzékeléssel rendelkező gépek és az automatizálás. A gyártás adaptívabbá tétele teret ad a gépi látás fejlődésének olyan területeken, mint a pozíciómeghatározás, objektumfelismerés és minőség-ellenőrzés.

\section{Minőség-ellenőrzés módszerei az iparban}

Egy automatizált gyártósori minőség-ellenőrzés célja az adott termékek megfelelőségének vizsgálata, amely megmutatja, hogy a termékek menynyire felelnek meg a rájuk vonatkozó nemzeti, szakmai, vállalati szabványoknak és jogszabályoknak és követelményeknek [1]. Az ellenőrzés mindig meghatározott anyagmennyiségre vagy tételmennyiségre vonatkozik. A folyamat lehet hagyományos és statisztikai elvü. Előbbi esetében az ellenőrzést végző személy joga az ellenőrzéshez szükséges minta megállapítása a termék és a 
gyártási folyamat jellege alapján. Utóbbi viszont rendszeres minőség-ellenőrzési számadatok gyűjtését jelenti, melyek statisztikai feldolgozásokon esnek át, mely segíti a csoportosítást és átlátást. Előnye, hogy a folyamatosságból adódóan időben folyamatos az ellenőrzési folyamat, így általános következtetések is levonhatók kevesebb adatból, valamint azok változásának jellege is nyomon követhető. Alapvetően 4 módozata ismeretes, melyek a 100\%-os minőség-ellenőrzés, a véletlenszerű minőség-ellenőrzés, a statisztikai mintavételes minőség-ellenőrzés és a gyártóinyilatkozat-alapú minőség-ellenőrzés [1].

A 100\%-os minőségellenőrzés esetén az ellenőrzési tétel a teljes terméktételszám. Az átvizsgálás a tétel minden darabjának átvizsgálást jelenti, azonban a vizsgálat csak bizonyos jellemzőkre korlátozódik. Előnye, hogy az adott jellemzőre teljes körű ellenőrzés valósul meg. Hátránya, hogy más hibák nem kerülnek detektálásra és roncsolásos vizsgálati módszerek nem alkalmazhatók [1].

A véletlenszerü minőség-ellenőrzés a teljes tétel darabszámának csak egy bizonyos részét jelenti (pl.: 10\%-át). A mennyiség szabadon választható [1].

A statisztikai mintavételes minőség-ellenőrzés hatékony és megbízható eredményeket szolgáltat. Előnye, hogy viszonylag kisszámú mintából a folyamatosságnak és a statisztikai módszereknek köszönhetően az eredményeket mégis nagy tételszámra lehet vonatkoztatni. Minősítésalapon kerül megállapításra, hogy a minta darabjai megfelelnek-e az előírt követelményeknek, mérésen alapuló módszer esetében viszont a mért értékek feljegyzésre és elemzésre kerülnek [1].

A gyártóinyilatkozat-alapú minőség-ellenőrzési módszer során a gyártó egy minőségi bizonyítványt ad ki arra vonatkozóan, hogy egy termék elérte-e az elvárt minőséget [1].

\section{Az optikai ellenőrzés elmélete}

\subsection{Az optikai ellenőrzés eszközei}

Az ipari minőség-ellenőrzési folyamatok során egyik legfontosabb technológia a gépi látás. Jellemzően a detektált jellemzők az adott termék valamely külső jellemzője, mely lehet geometriai jellemző, objektumok megléte vagy más optikai úton érzékelhető jellemzők.

Egységei az jelforrás és lényegkiemelés (kép és megvilágítás), a képalkotást megvalósító eszköz, a jelfeldolgozó egység, a szoftverkomponens és a kommunikációs csatorna [2].
A jelforrás lehet mozgó- vagy állókép. A lényegkiemelő eszköz megvilágítással (Reflected, Bright Field, Dark Field, szórt fényű, fókuszált stb.) javítja a mintavételezés és a kvantálás minőségét. A képalkotó eszköz igazodva a jelforrás fizikai tulajdonságához a jelfeldolgozó egységgel együttesen előállítják a digitális képet. A felhasználói kezelőfelület biztosítása a szoftverkomponens feladata, mely hozzáféréssel rendelkezik egy ismereti adatbázishoz, valamint rendelkezik a szükséges kommunikációs csatornával (pl.: Modbus TCP, EtherCAT) [3].

\subsection{A gépi látás folyamata}

A képfeldolgozás folyamatának első fázisa az előfeldolgozás, mely a nyers bemeneti adatokat egyszerű műveletek és szűrők segítségével készíti elő. Cél a felesleges képi információ elhagyása és a zavaró különbségek kiküszöbölése (pl. szürkeárnylatos konverzió alkalmazásával). Az előfeldolgozás folyamatai képpontok szintjén mennek végbe [4, 5].

A következő lépés a szegmentálás, mely szintén az értékes információk kiemelését és a felesleges eldobását célozza a kép jellemző területeinek szétválasztásával. Eszközei az éldetektálási algoritmusok, hisztogramgörbe-transzformációk a szín- és fényességi értékekre vonatkozóan [4, 5].

A szegmentálás és a karakterisztikus jegyek detektálásának információit leíró algoritmusok (descriptorok) tömörítik, így a felismerés folyamata már információalapú, nem képpontalapú. A folyamatot segíti az ismeretbázis, melynek elemei között összevetésre kerülnek a leíró algoritmusok információival. Lehet gyártó által biztosított vagy gyártófüggetlen könyvtár [4, 5].

A felismerés mellett modellillesztést is célozhat a gépi látás. Itt arról kell dönteni, hogy a leíró információk alapján egy adott modell illeszthető és feldolgozható-e. Ennek első lépése egyéni leírás társítása, a második pedig a modell beillesztése és finomhangolása[4, 5]. A gépi látás folyamatának lépéseit az 1. ábra szemlélteti.

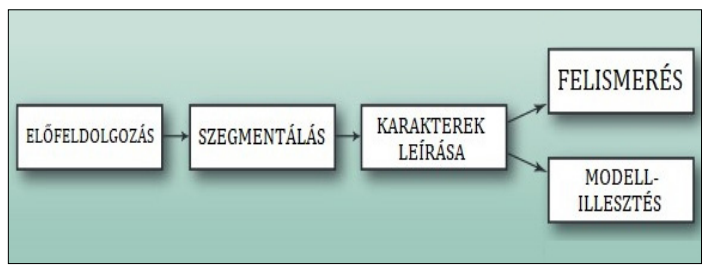

1. ábra. A gépi látás folyamatának lépései [4] 


\section{A CPVC-könyökidomok gyártása}

A PVC (Polyvinyl-chloride) a hőre lágyuló müanyagok csoportjába tartozik, amely $47 \%$ klórt és $43 \%$ szenet tartalmaz. A PVC újbóli klórozása hozza létre a CPVC-anyagot (Chlorinated polyvinyl-chloride), melynek fizikai és kémiai tulajdonságai jelentősen javulnak [6].

A hőre táguló műanyagok hő hatására képlékeny állapotba kerülnek, majd újra szilárd halmazállapotot vesznek fel. A folyamat megismételhető. $\mathrm{Az}$ alapanyag por vagy granulátum formájában kerül adagolásra. Míg a hőre lágyuló műanyag csövek extrudálással, addig a csőidomok fröccsöntési technológiával készülnek [7]. A 2. ábra egy fröcscsöntőgép vázlatát szemlélteti:

A gép meleg hengerében a csiga segítéségével megolvasztásra kerül (plasztifikálás) a granulátum, majd a csiga az előkészített ömledéket a fröccsöntőszerszám zárt üregébe préseli. Az ott létrejövő erőket a záróegység hivatott felfogni. A formázott ömledék hütése a szerszámon keresztül valósul meg az anyag megszilárdulásáig. Az osztott szerszám nyitását és az idom belsejét kialakító magok kihúzását követően az idom eltávolítható [7].

\section{Az optikai vizsgálat megvalósítása}

Az optikai ellenőrző eljárás a National Instruments által fejlesztett Vision Development Module-fejlesztőkörnyezetben készült. A szoftver alkalmas objektumok jelenlétének detektálására, felismerésére, számlálására, minta- és karakterfelismerésre, mozgó objektumok sebességének és vektorának mérésére, illetve feladatok elvégzésére frekvenciatartományban [8].

Az vizsgálat során az alábbi Genova-gyártmányú, 50705-ös típusú 1,2" derékszögű CPVC-könyökidomok külső geometriai paraméterei kerül-

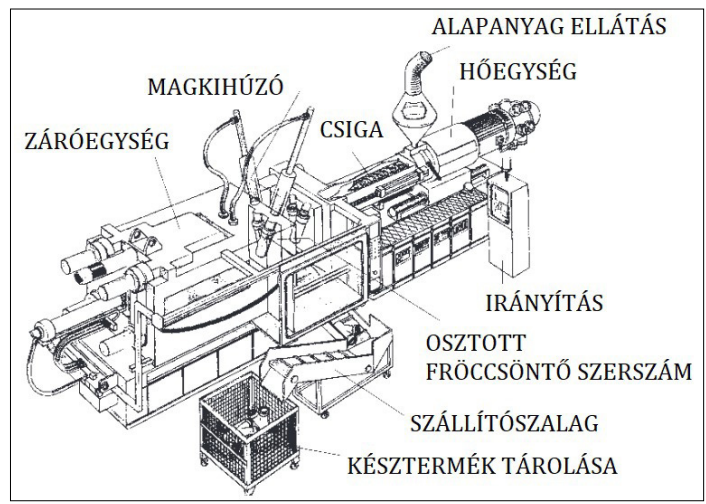

2. ábra. Fröccsöntőberendezés [7] tek ellenőrzésre [9]. Az alkatrész dimenziói [mm]ben értelmezve és a termék a 3. ábrán láthatók.

Az optikai vizsgálat 17 db képfeldolgozási szekvenciát foglal magában, az alábbi geometriai méretek kerülnek detektálával:

- a könyökidom csőátmérője (mindkét nyílás),

- a könyökidom hajlási szöge,

- a könyökidomok vertikális hossza,

- a könyökidomok horizontális hossza.

Első lépés a termékről készült digitális kép betöltése, mely $2268 \times 2271$ méretű, 24 bitmélységü sRGB színterü digitális kép. A feldolgozási folyamatok 24 bites bitmélységú képen RGB-színtérben erőforrásigényesek, így az eredeti képet egy Colour Plane Extraction funkcióblokk módosítja 8 bites mélységüre vörös színtér nélkül.

Az alakzatok változó pozícióval és orientációval rendelkeznek, így vonatkoztatási rendszer szükséges. Ennek során az aktuális könyökidom egy szeglete kerül betanításra és detektálásra a Find Base Coordinate Sytem funkcióblokkal, mely aktuális vonatkoztatási rendszerként szolgál a Define Coordinate System funkcióblokk révén.

A következő éldetektálási műveletek célja a csőnyílások megtalálása, az átmérők 2 végpontjai alapján az Upper- és Bottom Edge Detector funkcióblokkok segítségével. A keresés során adott vonal mentén kerül detektálásra a legelső és a legutolsó él, melyek az alkatrész kontúrjai. Az átmérők mérése az Upper- és Bottom Diameter Caliper funkcióblokkokkal történik a vonalmenti pixelszám alapján.

A következő mérendő geometriai tényező a hajlásszög, melynek névleges értéke $90^{\circ}$. Az éldetektálás 1 db helyett jóval több, a keresett élre merőleges keresővonallal történik. A vonalsürüség pontosabb detektálást eredményez, de a felesleges keresővonalak alkalmazása lassítja a feldolgozás sebességét. Az keresés során 1300x500 pixel

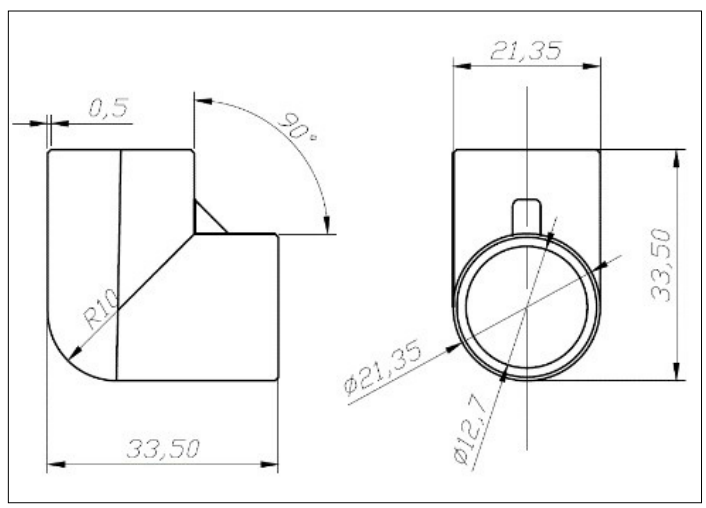

3. ábra. A CPVC-könyökidom méretei [mm] [10] 
területen, a hosszabb oldalra merőleges $90 \mathrm{db}$ keresővonal került alkalmazásra $40 \mathrm{~dB}$ küszöbértékkel, éldetektálási iránnyal és az intenzitásváltozás figyelésével. A hajlásszög mérését az Angle Caliper nevü funkcióblokk végezi a két oldalegyenes által bezárt szög alapján.

A könyökidom hosszméreteinek méréséhez definiálásra kerülnek a csőnyílások középpontjai, melyek az átmérőszakaszok felezőpontjai. A felezőpontokat a szemközti oldalegyenesekkel öszszekötő, oldalegyenesekre merőleges szakaszok hosszméretei megadják a keresett értékeket. Az merőleges egyenes állítása a Bottom- és Top Perpendicular Projection Caliper-blokkok révén, míg a keresett méretek meghatározása a Height és a Width blokkok révén valósulnak meg. A detektált geometriai paramétereket a 4. ábra szemlélteti:

\section{A gyártási hibadiagnosztika}

\subsection{Az optikai ellenőrzés eredményei}

Az optikai ellenőrzés során egy 30 db termékből álló minta került ellenőrzésre. Az adott optikai beállításokra vonatkozó pixelmilliméter-konverzióhoz egy gyárilag ellenőrzött, 15 db termékből álló minta került felhasználásra, melyek mérései eredményei az 1. táblázatban láthatok:

A pixelszámok nem egész értékek, melynek oka, hogy a képfeldolgozó eljárás a pontosabb mérés érdekében 100 pixel méretéből osztja vissza a mennyiségeket, századára csökkentve a mérési hibát. Az alkalmazott optikai beállítás esetén az alábbi megfeleltetés adódott:

\section{$1 \mathrm{~mm}=31,55$ pixel}

A gyári szabvány [mm], szög és pixel értékeit a 2. táblázat tartalmazza.

A 30 elemű minta optikai vizsgálatának eredményei Microsoft Excel-környezetben kerültek feldolgozásra (3. táblázat)

A vizsgálat során 1 db hibás termék került detektálásra, melynek a csőátmérő méretei lépték túl a megengedett tűrési értéket.

Az 5. ábra a paraméterek eloszlását szemlélteti:

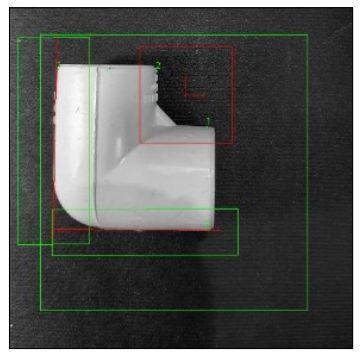

4. ábra. A detektált paraméterek
1. táblázat. A pixelmilliméter-konverzió eredménye

\begin{tabular}{|l|c|c|}
\hline & Manuális mérés & Optikai mérés \\
\hline Csőátmérő & $21,35 \mathrm{~mm}$ & 673,60 pixel \\
\hline Hosszméret & $33,50 \mathrm{~mm}$ & 1056,90 pixel \\
\hline Hajlásszög & $90^{\circ}$ & $90^{\circ}$ \\
\hline
\end{tabular}

2. táblázat. A névleges- és türésértékek átváltása

\begin{tabular}{|l|c|c|c|c|}
\hline \multirow{2}{*}{} & \multicolumn{2}{|c|}{ Névleges érték } & \multicolumn{2}{c|}{ Túrés } \\
\cline { 2 - 5 } & {$[\mathrm{mm}]$} & [pixel] & {$[\mathrm{mm}]$} & [pixel] \\
\hline Csőátmérő & 21,35 & 673,60 & $\pm 0,1$ & $\pm 3,2$ \\
\hline Idomhossz & 33,50 & 1056,90 & $\pm 0,5$ & $\pm 15,8$ \\
\hline Hajlásszög & $90^{\circ}$ & $90^{\circ}$ & $\pm 0,5^{\circ}$ & $\pm 0,5^{\circ}$ \\
\hline
\end{tabular}

\section{3. táblázat. A rendszerezett eredmények}

\begin{tabular}{|l|c|c|}
\hline & Átlag & Szórás \\
\hline Csőátmérő & $21,3464 \mathrm{~mm}$ & $0,03236 \mathrm{~mm}$ \\
\hline Idomhossz & $33,4802 \mathrm{~mm}$ & $0,12474 \mathrm{~mm}$ \\
\hline Hajlásszög & $90,07^{\circ}$ & $0,05801^{\circ}$ \\
\hline
\end{tabular}

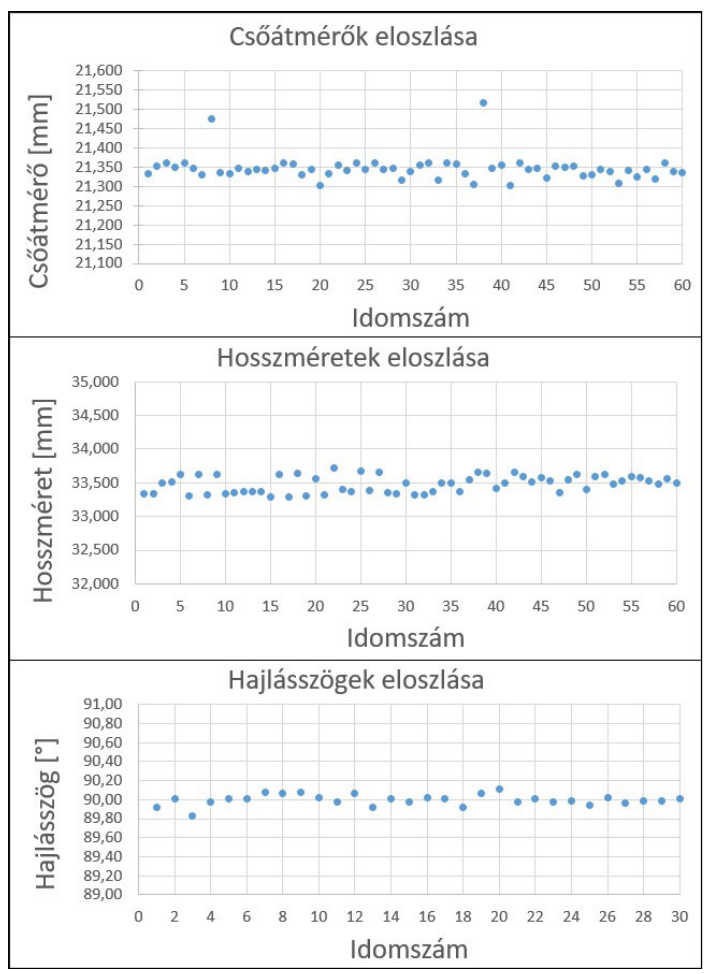

5. ábra. A vizsgálat eredményeinek eloszlása 


\subsection{Hibadiagnosztika a gyártási folyamatra}

Az optikai vizsgálat eredménye szemlélteti, hogy a minta többi eredménye a megadott tartományokon belül hol helyezkedik el, tehát képes-e a gép adott minőségű termék gyártására, vagy sem. Definiálható gépképesség és folyamatképesség [10]:

$$
\begin{aligned}
& C_{p}=\frac{F T H-A T H}{6 \cdot \sigma} \\
& C_{p k}=\left\{\frac{\mu-A T H}{3 \cdot \sigma} ; \frac{F T H-\mu}{3 \cdot \sigma}\right\}_{\min } \\
& C_{m}=\frac{F T H-A T H}{8 \cdot \sigma} \\
& C_{m k}=\min \left(C_{m l} ; C_{m u}\right)=\min \left\{\frac{\mu-A T H}{4 \cdot \sigma} ; \frac{F T H-\mu}{4 \cdot \sigma}\right\}
\end{aligned}
$$

ahol,

-FTH/ATH - türési határok [mm],

$-\mu$-átlagérték [mm],

$-\sigma-$ szórás [mm],

$-C_{p} / C_{m}-$ folyamat/gép képességének indexe,

$-C_{p k} / C_{m k}-$ a folyamat/gép aktuális képességének indexe [10].

A gépképesség egyetlen gépre vagy műveletre vonatkozik. A cél, hogy a minimalizálhatók legyenek a nagy változásokat előidéző hibafaktorok. A folyamatképesség a vizsgált paraméter változását előidéző minden hatást igyekszik figyelembe venni (4. táblázat) [10].

A gyártás során az alkatrészek külső átmérője bizonyult a kritikus paraméternek. A mérőszám (átmérő [mm]) valószínűségi változója normális eloszlást mutat. Mivel az átmérőre számolt $C_{p}=1,02995$, így a természetes ingadozása $\pm 3 \sigma$ mellett a türésmező a középérték körül

4. táblázat. A folyamat- és gépképességi indexek értékei

\begin{tabular}{|l|c|c|c|c|}
\hline \multirow{2}{*}{} & \multicolumn{2}{|c|}{ Folyamatképesség } & \multicolumn{2}{c|}{ Gépképesség } \\
\cline { 2 - 5 } & $\boldsymbol{c}_{\boldsymbol{p}}$ & $\boldsymbol{c}_{\boldsymbol{p} \boldsymbol{k}}$ & $\boldsymbol{C}_{\boldsymbol{m}}$ & $\boldsymbol{C}_{\boldsymbol{m}}$ \\
\hline Átmérő & 1,0299 & 0,9928 & 0,772463 & 0,7446 \\
\hline Hossz & 1,3361 & 1,2832 & 1,00212 & 0,9624 \\
\hline Szög & 2,8731 & 2,8578 & 2,154834 & 2,1433 \\
\hline
\end{tabular}

$\mathrm{SL}=3 C_{p}=3,089$ szórásegységet tartalmaz. Ennek megfelelően a $C_{p k}=0,9928$ értéke azt mutatja, hogy a várható érték az alsó türéshatárhoz van közelebb, a határon kívül esés mértéke kisebb, mint $0,27 \%$ [10].

\section{Következtetések}

A vizsgálat eredményének fényében a gyártósor képes a vevői igényeket kielégíteni. A gyártási folyamat stabil, szabályozott, csak véletlen hibákra lehet számítani. A minta számának növelése és gyakoribb vizsgálata még hitelesebb képet ad, beleértve a gyártósoron készített termékek időbeni változását.

\section{Szakirodalmi hivatkozások}

[1] A minőség-ellenőrzés módszerei, „Way of Cargo”. http://wocargo.hu/a-minoseg-ellenorzes-modszerei/. (letöltve: 2021. január 20.).

[2] B. Hope. A. Rosenfeld. J. Beck: Human and Machine Vision. Academic Press, 1983.

[3] Brilakis I. , Haas C. T. M.: Infrastructure Computer Vision. Butterworth-Heinemann, 2019.

[4] Vass G.: Gépi látás. I. rész, „Videó és PC”, Videopraktika 2006/4. (letöltve: 2021. január 20.). http://www.vassg.hu/pdf/gepilatas1.pdf

[5] Z. D. V. S. D. S. A. Dr. Rövid, The Parallel Models and Algorithms of the Machine Vision and Image Processing. Budapest: Typotex, 2014.

[6] CPVC-csövek technológiája, „Falcrumcontruction”. (letöltve: 2021. január 20.).

https://hun.falcrumconstruction.com/trubahpvh-chto-jeto-takoe.html.

[7] Bacsinszky T., Mészáros P.: Müszaki segédlet. 1. kiadás, Wavin-Pemü Kft, Mészáros és Társa Mérnöki Tanácsadó Közkereseti Társaság, 1998.

[8] Vision, National Instruments (letöltve: 2021. január 20.). https://www.ni.com/hu-hu.html

[9] Surman V.: Minőségmenedzsment. 19. Előadás 04.16., Menedzsment és Vállalkozásgazdaságtan Tanszék, Gazdaság- és Társadalomtudományi Kar, Budapesti Müszaki és Gazdaságtudományi Egyetem. (letöltve: 2021. január 20.)

www.uti.bme.hu

[10] Plumbing Catalog 2014, „Genova Products”. (letöltve: 2021. január 20.). www.genovaproducts.com 